Article

\title{
Corporate Hypocrisy and Counterproductive Work Behavior: A Moderated Mediation Model of Organizational Identification and Perceived Importance of CSR
}

\author{
Qing Miao *D and Jun Zhou \\ Center of Social Welfare and Governance, Academy of Social Governance, Zhejiang University, \\ Hangzhou 310058, China; 11822062@zju.edu.cn \\ * Correspondence: mqok@zju.edu.cn
}

Received: 16 January 2020; Accepted: 24 February 2020; Published: 1 March 2020

\begin{abstract}
When companies say one thing and do another in a corporate social responsibility context, they run the risk of corporate hypocrisy. Apart from the negative attitudes within customers, the purpose of our study was to explore what consequence corporate hypocrisy would cause on employees. This study investigated the possible link between corporate hypocrisy and employees' counterproductive work behaviors with a moderated mediation model. Based on social identity theory, our research found that the influence of corporate hypocrisy on organization-directed counterproductive work behaviors was partially mediated by organizational identification, while the first stage of mediation is moderated by the levels of employees' perceived importance of corporate social responsibility. Data from 259 employees in China, collected across three time periods, suggest that corporate hypocrisy will lead to a decrease of organizational identification, triggering CWB against the company. The indirect effect of corporate hypocrisy on CWB-O via organizational identification is enhanced when employees' perceived importance of corporate social responsibility is high. Our findings provide contributions to both corporate running and theoretical research.
\end{abstract}

Keywords: corporate hypocrisy; counterproductive work behavior; organizational identification; corporate social responsibility

\section{Introduction}

Companies have been placing more importance on and increasingly holding corporate social responsibility (CSR) activities during the last decades [1], considering the benefits that companies can reap from their active involvement in CSR (e.g., [2-4]). However, not every company can do what it says. Companies can show their public virtues while ignoring internal moral standards through CSR strategy (e.g., [5,6]), which reveals the nature of hypocrisy. Corporate hypocrisy has been defined as a belief that the company claims to be something that it is not [7] (p. 79). For example, the Volkswagen 2015 emissions scandal shocked the world and led to the resignation of chief executive officer and a huge fine [8]. However, as stated in Volkswagen's 2014 Sustainability Report, "A sustainable supply chain and environmentally compatible transportation solutions form an indispensable part of demonstrating comprehensive responsibility for human rights, as well as a commitment to the environment" [9]. Although Nongfu Spring, one of China's largest producers of bottled water and beverages, made a public promise to donate $0.1 \mathrm{RMB}$ per one bottle sold, the media later reported that the donation was far less than it should have been [10]. Similarly, McDonald once faced harsh denouncement from some activist groups, disclosing that it was a minor contributor (20\%) to its own charity, the Ronald McDonald House [11]. Such deviations between public CSR statements and private 
firm practices revealed by other sources could cause dramatic effects on the image of the company, leaving a hypocritical impression [7].

When the company speaks in one way and behaves in another, pretending to have a good face to win good fame, they may fall into the trap of hypocrisy. It is common for companies to publicize and carry out CSR activities. However, slogans alone are not enough. Apart from behaving in a socially responsible manner, the company's practical actions must be responsible if it expects to get rewards [12]. In particular, inconsistency about a company's stated policies and their private practice may cause more serious problems than arousing public attention. Consumers' perceived hypocrisy reflects the ethical judgment of firms' beneficent or virtuous efforts [13]. When motives of CSR activities are perceived as insincerity, the company's image will also be hurt [14].

Most existing studies have been rooted in the positive outcomes of CSR strategy; however, the hidden side of hypocrisy should also be paid attention to. Despite research in recent years contributing to our understanding of the perception of corporate hypocrisy (e.g., $[7,13,15,16])$, few studies have examined the consequences of corporate hypocrisy on stakeholders, such as employees. Ford and Richardson [17] pointed out that situational factors often exert influences on an individual's ethical or unethical decision behavior. As CSR publicity has been proven to be positively linked with employees' organizational citizenship behavior (OCB) (e.g., [18,19]), and can even act to some extent as a preventive against counterproductive work behavior (CWB) (e.g., [20,21]), we wonder whether the hypocrisy of a corporation may affect employees' CWB. Employees often engage in CWB in an organization [22], and by studying the relationship between corporate hypocrisy and CWB, we can obtain a better understanding of how corporate hypocritical behavior can exert a negative influence on employees' behaviors. To date, no published study has investigated the relationship between corporate hypocrisy and CWB. Since CWB can often be categorized into two types depending on its target, organization-directed (CWB-O) and individual-directed (CWB-I), we incorporate both types in our model.

Existing evidence suggests that organizational identification can be an underlying mechanism that explains employees' behavioral and attitudinal outcomes in the workplace (e.g., [23,24]). A good public image created by the company, through actively participating in CSR activities, has been frequently related to the organizational identification of employees in previous research (e.g., [25-29]). Based on social identity theory, we link corporate hypocrisy with organizational identification to see whether hypocritical behavior in CSR context may change employees' sense of identity about the corporation, thus leading to CWB. In other words, if the public slogan or CSR strategy turns out to be a lie, will the organization's prestigious image be tarnished, and will the employee perform CWB that damages the interests of the company? In this way, we can learn more about organizational identification functioning as a mediator between corporate practice and employees' practices, which can help show the mechanisms through which corporate hypocritical practices impact employees' attitudes. Ciampa et al. [30] also confirmed the negative relationship between organizational identification and CWB. Concerning the situational-individual interaction effect [31], we include employees' perceived importance of CSR into our model as a moderator to see if an individual's value of CSR will make any difference.

Our research makes several contributions by enriching the corporate hypocrisy literature. Firstly, the study reveals the hidden effect of corporate hypocrisy on inner stakeholders, one that has been neglected to date, by focusing on the relationship between employees' perceptions of corporate hypocrisy and practice of CWB. Secondly, this study suggests a research model that focuses on the bridging role of employee organizational identification moderated by the perceived importance of CSR, explaining the inner mechanism of employees' behaviors, while at the same time contributing to the use of social identity theory. Thirdly, the results of the study can also be useful for organizational practitioners especially when implementing and evaluating CSR strategies. 


\section{Literature Review and Hypotheses Development}

\subsection{Corporate Hypocrisy}

The charge of hypocrisy stems from clear inconsistencies between words and deeds. Moral hypocrisy has been explained as the desire to appear moral but avoid the cost of actually being so if possible [32]. The concept can be described as a person's dispositional characteristic and is applicable to organizations, brands, or companies, since people perceive hypocrisy originating from diverse corporate practices [33]. Corporate hypocrisy has been defined as a belief that the company claims to be something that it is not [7] (p. 79). In other words, corporate hypocrisy is a stakeholder's belief that a company has failed to deliver on its promises [16] (p. 2). The gaps between a firm's goals and practices towards sustainability can also create perceived corporate hypocrisy within and outside the company [34] (p. 8). The dissonance between rhetoric about CSR or business ethics on the one hand and actual corporate behaviors on the other can often be staggering [35]. It is believed that corporate hypocrisy should be avoided by overcoming the threat of inconsistent corporate social responsibility perceptions [7]. According to Wagner et al. [7], a company's chosen communication strategy would affect corporate hypocrisy. If the conflicting corporate behaviors are observed after the CSR publicity, the sense of corporate hypocrisy will increase, leading to negative attitudes towards the firm. However, if the companies choose an innocuous communication way and a vaguely defensive way, this may help reduce the sense of hypocrisy as well as its effect on negative feelings toward the firm.

Few researchers have considered hypocrisy as a necessary choice when corporations must satisfy different and conflicting needs, such as those from shareholders or the rest of society [36]. More scholars consider corporate hypocrisy as the pursuit of short-term benefits, as the only thing that truly matters is increased sales (e.g., $[7,13,15,16])$. However, corporate hypocrisy can actually become troubling when corporations are caught in a dilemma where this contradiction becomes apparent to the society at large [37], such as the example of Volkswagen mentioned above. According to Bae and Cameron [38], the perceived altruistic motives of CSR might cause employees to be optimistic toward the firm, whereas selfish motives might trigger employees' passive attitudes toward the firm. Corporate hypocrisy could also interfere with consumers' feelings toward the firm [13] and negatively impact the corporate reputation in terms of suspicious CSR motives [14]. Arli et al. [16] proved that corporate hypocrisy would exert a negative impact on consumers' perceived reputation of the corporation. The current research on the impact of corporate hypocrisy is basically focused on the perspective of customers (e.g., $[7,13,16])$. Compared to customers, we believe that employees, as actual participators and internal observers of corporate behaviors, are better able to recognize corporate hypocrisy. Thus, it is necessary to examine the impact of corporate hypocrisy on employees.

\subsection{The Main Effect of Corporate Hypocrisy on CWB}

To date, no study has focused on the influence of corporate hypocrisy on employees' behavior. We think corporate hypocrisy can exert a bad influence on employees, like CWB. CWB refers to behavior by employees that harms an organization or its members, and includes acts, such as sabotage, withholding effort, refusing to cooperate, breach of confidence, workplace gossiping, and rudeness towards others [39]. CWB is the result of a complex interaction between the individual and the environment, as the interpretation of a negative outcome is a primary driving force in determining whether to conduct CWB or not [40].

Ford and Richardson [17] pointed out that situational factors often exert influences on an individual's ethical or unethical decision-making behavior. In this study, we propose that corporate hypocrisy can exert a promotive influence on employees' CWB. Employees are working within a shared social context pervaded by common values, codes, and standards of behaviors [41]. Based on the social identity theory, when employees perceive corporate hypocrisy, unethical and self-interested practice cause them to abandon the moral values and norms, thus leading to their antipathy and disagreement with this phenomenon. 
In our case, when people perceive corporate hypocrisy behavior, they may think of it as a stain on the organization, especially when compared to those that do as they say in a sincere way to put CSR strategy into practice. Under this logic, they may no longer regard themselves as 'loyal' members of the organization. Employees will suffer from disappointment caused by the membership of the hypocritical organization, thus weakening their belongingness to organizations. The identity of the organization will be damaged and replaced by suspicion, thus leading to CWB, like depression, demotivation, or low performance. More likely, the corporate hypocrisy conducted by a company seems to help make numerous profits for the company by cheating the whole of society. Even if corporate hypocrisy is exposed by social media, the accompanying punishment often ends up with nothing definite or seems inadequate to make up for the harm it causes, not to mention the difficulty to discover the corporate hypocrisy. Companies' ignorance of moral standards and commercial integrity can wear down employees' identification, leading to employees' objection or criticism to the company with retaliatory behaviors, like sabotage or breach of confidence. Under this situation, companies no longer deserve their identification, respect, or devotion, and thus CWB can help reach their purpose of denial.

Furthermore, $\mathrm{CWB}$ can be classified as counterproductive work behavior against the organization as a whole (CWB-O) or counterproductive work behavior against the individuals within the organization (CWB-O). In detail, CWB-O includes behaviors, such as stealing company's property; CWB-I includes acts of aggression toward colleagues, such as making fun of others [42]. Like many other empirical studies that have adopted this classification (e.g., [43-45]), this study contributes to a more nuanced view of the impact of corporate hypocrisy on employees' behavior in this way. Ciampa et al. [30] also classified CWB as CWB-O and CWB-I to explore the negative relationship between organizational identification and CWB. Since organizational hypocrisy reflects the hypocritical level of the whole organization, we are curious whether organizational hypocrisy will have different effects on CWB targeted on the organization as a whole and the individuals within.

Therefore, we hypothesized the following:

Hypothesis 1a (H1a): Corporate hypocrisy is negatively related to the CWB-O of an employee.

Hypothesis $\mathbf{1 b} \mathbf{~ ( H 1 b ) : ~ C o r p o r a t e ~ h y p o c r i s y ~ i s ~ n e g a t i v e l y ~ r e l a t e d ~ t o ~ t h e ~ C W B - I ~ o f ~ a n ~ e m p l o y e e . ~}$

\subsection{Mediator of Organizational Identification}

Little research has focused on the inner mechanism when exploring the effects of corporate hypocrisy. Lee et al. [46] pointed out how employees' perceptions of internal legitimacy in line with the firm's mission and values in the firm's CSR activities would be considered more authentic than external legitimacy, and that it would have a more positive impact on employees' organizational identification. We believe that, compared with the blind belief with CSR slogans, internal employees would have a higher probability of discovering corporate hypocrisy, thus having a negative impact on their organizational identification and behavior.

Organizational identification has been defined as an individual's sense of oneness or belongingness within a group [47]. Based on social identity theory [47], individuals tend to distinguish themselves and others based on social categories. They are inclined to define the self-concept view of themselves according to their memberships of a particular social group. As representative social groups, organizations like companies often exert significant effects on its members, namely employees. Employees view their organizational belongingness or identification as a significant dimension that helps describe their identity and shape their self-concept. Thus, the social identification of the company provides employees with normative guidelines, which can help them define who they are, how to behave, and which aspects of their group belongingness are especially important in daily work [48].

Moreover, individuals are more inclined to emphasize their self-concept by recognizing that their own groups are better than all the other organizations in social identity theory [49]. Organizations 
with good fame [50] and higher employee-perceived organizational ethics [51] often lead to higher organizational identification. Corporate publicity and slogan-related CSR choices have frequently been connected with organizational identification of employees (e.g., [25-29]). For example, when the company conducts good publicity and packages its own image, such as promoting CSR activities to contribute to society, it can substantially enhance the employer-employee relationship [52]. It is acknowledged that a firm's interest and commitment to CSR generally improves its reputation, so that employees are more likely to be proud of and make a commitment to their company due to its prestigious image (e.g., [53-60]). However, companies playing tricks in fulfilling their social responsibilities, which reveals corporate hypocrisy, may lead to negative evaluations of customers [7]. Perceived corporate hypocrisy of employees may seem to be related with their feelings and employment expectations [61]. Corporate hypocrisy occurs when corporations sacrifice ethics and morality for short-term benefits. It not only violates acquiescent norms and rules but also creates suspicion and disappointment in employees due to belonging to such an inferior group, which we believe will lead to lower identification with the firm.

Organizational identification can exert an influence on members' behavior by affecting their cognitive and emotional processes [49]. Organizational identification fundamentally transforms the relationship between employees and organizations, as employees integrate their group memberships with their sense of who they are, thus affecting their work performance [62]. Scholars have found that those employees who most strongly identify with the organization were least likely to engage in deviance behaviors [63] and had lowest turnover intentions [64]. We presume that when employees perceive corporate hypocrisy, they form negative evaluations of the company and may even turn against their organization with CWB. Ciampa et al. [30] also confirmed the negative relationship between organizational identification and the CWB of employees. When the identification with the organization is hurt, employees may turn to CWB, like depression, demotivation, or low performance, with suspicion of whether or not to keep their belongingness. Concerning the cunning of corporate hypocrisy and its potential bad consequences, apart from wearing down employees' identification, it may lead to objection or criticism toward the company with retaliatory behaviors, like sabotage or breach of confidence. Under this situation, companies no longer deserve their identification, belongingness, or devotion, thus CWB can help reach their purpose.

Although organizational identity has not been tested between the negative effects of corporate hypocrisy before, some corroborative evidence supporting the idea that organizational identification serves as the mediator between corporate practice and individual outcomes exists. Shin et al. [20] pointed out that CSR would enhance employees' organizational commitment and thereby hinder their CWB. Kim et al. [65] demonstrated that CSR positively influences organizational commitment through the mediation of organizational identification. The research of El-Kassar et al. [66] indicated that employee identification mediates the relationship between CSR and normative commitment. Hur et al. [21] explained with social identity theory that CSR perceptions influence employees to cultivate organizational civil norms in order to further enhance their positive identification with their organization, which prevents employees from engaging in CWB.

Therefore, we suppose that employees who negatively appraise corporate hypocrisy practices are less identified with their organization and may lead to CWB instead. Thus, we hypothesized the following:

Hypothesis 2a (H2a): Organizational identification mediates the relationship between corporate hypocrisy and CWB-O.

Hypothesis $\mathbf{2 b} \mathbf{( H 2 b ) : ~ O r g a n i z a t i o n a l ~ i d e n t i f i c a t i o n ~ m e d i a t e s ~ t h e ~ r e l a t i o n s h i p ~ b e t w e e n ~ c o r p o r a t e ~ h y p o c r i s y ~}$ and CWB-I. 


\subsection{Moderator of the Perceived Importance of CSR}

To examine the mechanism through which corporate hypocrisy exerts an influence on employees' behavior, further thinking is needed. The situational-individual interaction model reminds us to take the interaction of the corporate and individual elements into consideration [31]. We believe not every employee reacts in the same way when facing corporate hypocrisy. Our study proposes that there will be individual differences in the extent to which they are sensitive to corporate hypocrisy. Given corporate hypocrisy's special role in the CSR context, we chose the perceived importance of CSR as a moderator between corporate hypocrisy and organizational identification.

The perceived importance of CSR has been described as an important determinant of actual business behavior, since it can help predict the propensity of business managers to engage in ethical or socially responsible behavior [67]. For example, the more companies believe in the importance of CSR for the success and survival of their business, the more they will engage in CSR activities. To organizational effectiveness, the perceived importance of ethics and social responsibility are likely to be a critical determinant of whether a moral problem is even reflected on in a given situation, as well as a determining factor of variables, such as deontological norms and the importance of stakeholders, among others [68].

Similarly, from the employees' perspective, the perceived importance of CSR will affect employees' perception of corporate hypocrisy, thus determining to what extent they will let this element affect their attitudes. If employees' perceived importance of CSR is low, we believe that they may pay less attention to corporate hypocrisy as they may pay less attention to the company's external publicity, slogan, or specific implementation status of CSR activities. In other words, even if they are aware of the problem of corporate hypocrisy, they do not value the sense of responsibility and consider the related issues insignificant matters. As a result, they may treat corporate hypocrisy indifferently without causing any negative evaluation of the organization or a decline of identification. In the opposite way, an employee with a high level of perceived importance of CSR may have a higher probability of finding discrepancies between the organization's slogan and actual behavior since they pay more attention to related phenomena. More importantly, they may react dramatically and sensitively to the recognition of corporate hypocrisy, thus leading to bad evaluations of their organizations and a significant decrease in organizational identification. The relationship between corporate hypocrisy and organizational identification is strengthened in this way. Therefore, we hypothesized the following:

Hypothesis 3 (H3): The negative association between corporate hypocrisy and organizational identification is moderated by the perceived importance of CSR, such that it is stronger for higher levels of perceived importance of CSR than lower levels.

Furthermore, given the moderation hypothesis (H3) and the notion that employees' perceived importance of CSR also influences their tendency to act negatively, the perceived importance of CSR could also moderate the mediation of organizational identification, thereby demonstrating a model of moderated mediation. Thus, we hypothesized the following:

Hypothesis 4a (H4a): The mediating effect of organizational identification is moderated by the perceived importance of CSR, such that the indirect effect of corporate hypocrisy on CWB-O via organizational identification will be stronger when the perceived importance of CSR is high than when it is low.

Hypothesis $\mathbf{4 b} \mathbf{b} \mathbf{H} \mathbf{4} \mathbf{b})$ : The mediating effect of organizational identification is moderated by the perceived importance of CSR, such that the indirect effect of corporate hypocrisy on CWB-I via organizational identification will be stronger when the perceived importance of CSR is high than when it is low.

These relationships and hypotheses suggest the model in Figure 1. We propose that corporate hypocrisy positively impacts employees' counterproductive work behavior, including 
both organization-directed CWB (CWB-O) and individual-directed CWB (CWB-I). Our study develops a theoretically complex model, which simultaneously examines the process and boundary condition of these linkages. Based on social identity theory, we demonstrate that organizational identification of employees works as the mediator of the model. The unethical and insincere corporate hypocrisy perception may reduce the organizational identification of employees, thus exerting a potential influence on their behaviors, like CWB. The perceived importance of CSR moderates the mediation process as employees would be more sensitive to the hypocrisy between words and deeds when they put more importance on the CWB-related context; in the opposite way, they may be apathetic about corporate hypocrisy.

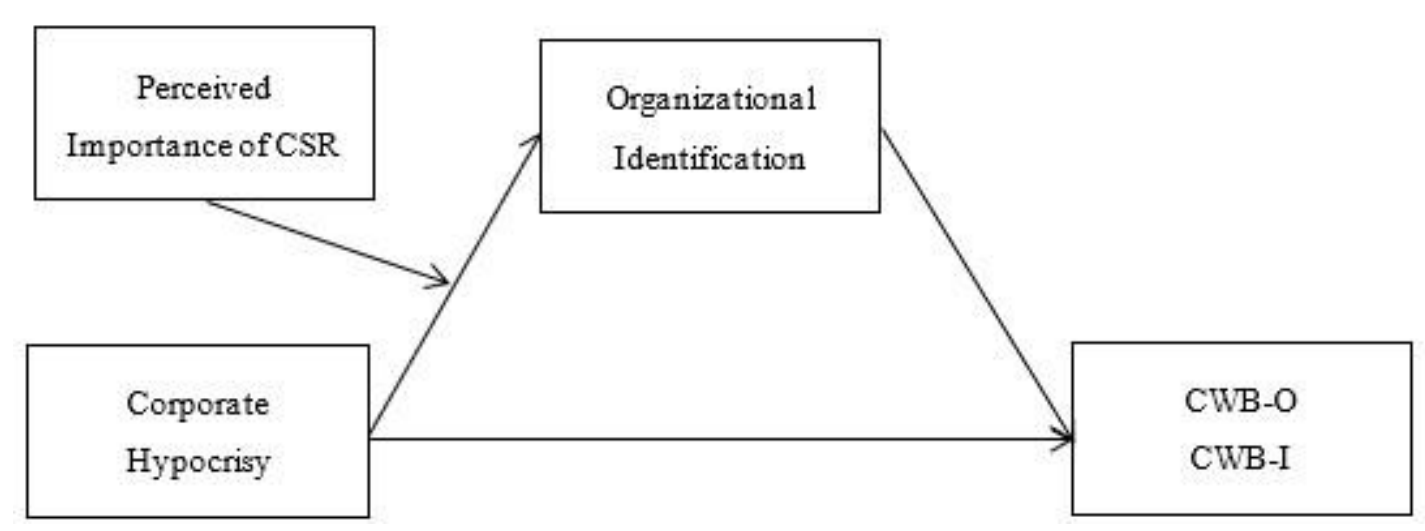

Figure 1. Hypothesized research model.

\section{Research Methods}

\subsection{Data Collection}

We drew our sample from a large manufacturing company in China employing thousands of workers and hundreds of managers. The company's products span 20 provinces, municipalities, and autonomous regions and are exported to various international markets. According to its Human Resource department, the company has taken part in CSR activities in the local market, such as donating money to local charities.

Four hundred employees were randomly selected from the name list provided by the HR department. We then highlighted the voluntariness and confidentiality of their participation when they were invited to a workshop to understand the survey process. In appreciation of their participation, we gave them a small gift worth 100 renminbi (approximately US \$15) afterwards. Prior to distribution, the survey was translated into Chinese based on the back-translation procedure [69].

We undertook our data collection through three waves during the period from May to November 2017. Questionnaires were directly distributed to participators in the beginning of the workday and gathered at the end of the workday through our project mail.

We collected data through three time periods to minimize common method bias [70]. The use of a longitudinal design enhances internal validity by ensuring temporal separation, thus eliminating the limitation of testing causal mediation models with cross-sectional data. By time one, we collected data from employees about their perceptions of corporate hypocrisy and perceived importance of CSR, as well as the information of the demographic variables. By time two, three months later, we asked employees to rate their sense of organizational identification. Lastly, at time three, another three months later, we gathered data from employees on reports of CWB.

From the sample of 400 employees, 263 completed questionnaires were turned in. We then deleted 4 responses due to incomplete information. This amounted to a total response rate of $64.75 \%$. Based on the responses of these 259 employees, a sample descriptive analysis showed that $54.8 \%$ of the 
participants were male, with an average age of 30.78 years $(\mathrm{SD}=6.19)$. A majority of the subjects $(63.3 \%)$ had a four-year university education.

\subsection{Measures}

\subsubsection{Corporate Hypocrisy}

We measured corporate hypocrisy with a 3-item scale developed by Wagner et al. [7]. A sample item is, 'Company pretends to be something that is not'. The response scale ranged from 1 ('strongly disagree') to 5 ('strongly agree'). The internal consistency was 0.79 .

\subsection{2. $\mathrm{CWB}$}

CWB was measured using a 19-item scale adapted from Bennett and Robinson [42]. It can be divided into two categories: CWB-O and CWB-I. The response scale ranged from 1 ('strongly disagree') to 5 ('strongly agree'). Given the reality of Chinese companies, we adapted the questionnaires. We used 11 items to examine CWB-O, such as 'intentionally worked slower than you could have worked'. The internal consistency of the CWB-O questionnaire was 0.91 . We also used 6 items to examine CWB-I, such as 'made fun of someone at work'. The internal consistency of the CWB-I questionnaire was 0.88 .

\subsubsection{Organizational Identification}

Organizational Identification was measured using a 5-item scale from the survey of Mael and Ashforth [49]. A sample item is, 'When someone criticizes our organization, it feels like a personal insult'. The response scale ranged from 1 ('strongly disagree') to 5 ('strongly agree'). The internal consistency was 0.83 .

\subsubsection{Perceived Importance of CSR}

The perceived importance of CSR was measured with the 5-item scale adapted by Etheredge [71]. Participants responded to items, such as 'Being ethical and socially responsible is the most important thing a firm can do'. The response scale ranged from 1 ('strongly disagree') to 5 ('strongly agree'). The internal consistency was 0.79 .

\subsubsection{Control Variables}

This study controlled for age (in years), sex (male $=1$, female $=2$ ), and education, which contains four dummy variables (coded 1-4): 'high school education', '2-year vocational college school', 'four-year university education', and 'graduate school education'. These variables were controlled when analyzing the hypotheses since they were shown to be related to OI or CWB in existing studies (e.g., $[20,26,29,72])$.

\section{Results}

\subsection{Descriptive Statistics}

Table 1 presents the means and standard deviations for each scale. The interscale correlations show that the expected directions of the association among the scale variables are all significant at the $p<0.01$ level.

Concerning the control variables, sex was significantly negatively related to both CWB-O and CWB-I, indicating that males tended to engage in more CWB than females. The same result was shown in a recent paper [20]. In addition, correlation coefficients higher than 0.7 could increase the likelihood of multicollinearity in the regression [73]. However, except CWB-O and CWB-I, corporate, hypocrisy and CWB-O, all correlations of variables in our study were below this threshold, indicating that all measures were appropriate for the results from the analyses. 
Table 1. Descriptive statistics, mean, standard deviation, and correlations.

\begin{tabular}{|c|c|c|c|c|c|c|c|c|c|}
\hline Variables & $\mathbf{M}$ & SD & 1 & 2 & 3 & 4 & 5 & 6 & 7 \\
\hline 1. Age & 30.78 & 6.19 & & & & & & & \\
\hline 2. Sex & 1.45 & 0.50 & -0.087 & & & & & & \\
\hline 3. Education & 3.87 & 0.69 & -0.193 ** & 0.049 & & & & & \\
\hline 4. $\mathrm{CH}$ & 3.08 & 1.05 & -0.002 & -0.138 * & $-0.135 *$ & & & & \\
\hline 5. OI & 3.35 & 0.80 & 0.078 & 0.022 & 0.062 & $-0.431^{* *}$ & & & \\
\hline 6. ICSR & 3.46 & 0.72 & -0.052 & 0.078 & 0.137 * & $-0.276^{* *}$ & $0.192 * *$ & & \\
\hline 7. CWB-O & 2.85 & 0.88 & 0.000 & $-0.190 * *$ & -0.108 & $0.732 * *$ & $-0.414^{* *}$ & $-0.317 * *$ & \\
\hline 8. CWB-P & 2.78 & 0.97 & 0.038 & -0.202 ** & -0.082 & $0.696^{* *}$ & $-0.369^{* *}$ & $-0.352 * *$ & $0.894^{* *}$ \\
\hline
\end{tabular}

\subsection{Measurement Models}

All the measurement items showed acceptable reliability, with composite reliabilities ranging from 0.79 to 0.91 . To avoid common method bias, we took suggestions with the use of established scales only [74]. We also explained the procedures to the participators and guaranteed their anonymity. Moreover, we used filler items and various instructions to create psychological separation for different variables. Next, we conducted confirmatory factor analysis (CFA) using the Amos 18.0 program to verify the convergent and discriminant validity of the measurement scales. The results are shown in Table 2. We calculated six fit indices to determine how the model fitted our data [75]. Here, $\chi^{2} / \mathrm{df}$ values less than 2.5 indicate a good fit [76]. For the Tucker-Lewis index (TLI), incremental fit index (IFI), and comparative fit index (CFI), values greater than 0.9 indicate a good model fit [77], and for the root mean square error of approximation (RMSEA), values less than 0.08 represent a good model fit $[78,79]$.

Table 2. Fit indices of confirmatory factor analysis models.

\begin{tabular}{cccccccc}
\hline Models & $\chi^{\mathbf{2}} \mathbf{( d f )}$ & $\mathbf{d f}$ & $\chi^{\mathbf{2}} / \mathbf{d f}$ & IFI & TLI & CFI & RMSEA \\
\hline Full measurement model $^{\text {M }}$ & 634.858 & 424 & 1.519 & 0.934 & 0.937 & 0.943 & 0.045 \\
Model A, four factors $^{\mathrm{a}}$ & 889.587 & 428 & 2.078 & 0.881 & 0.870 & 0.880 & 0.065 \\
Model B, four factors $^{\mathrm{b}}$ & 908.107 & 428 & 2.122 & 0.876 & 0.864 & 0.875 & 0.066 \\
Model C, four factors $^{\mathrm{c}}$ & 4308.992 & 465 & 9.267 & 0.000 & 0.000 & 0.000 & 0.179 \\
Model D, four factors $^{\mathrm{d}}$ & 4308.992 & 465 & 9.267 & 0.000 & 0.000 & 0.000 & 0.179 \\
Model E, three factors $^{\mathrm{e}}$ & 4308.992 & 465 & 9.267 & 0.000 & 0.000 & 0.000 & 0.179 \\
Model F, two factors $^{\mathrm{f}}$ & 4308.992 & 465 & 9.267 & 0.000 & 0.000 & 0.000 & 0.179 \\
Model G, one factors $^{\mathrm{g}}$ & 1322.389 & 434 & 3.047 & 0.771 & 0.752 & 0.769 & 0.089 \\
\hline
\end{tabular}

Notes: $\mathrm{n}=259, \chi^{2}$, chi-square discrepancy; $\mathrm{df}$, degrees of freedom; IFI, incremental fit index; TLI, Tucker-Lewis index; CFI, comparative fit index; RMSEA, root mean square error of approximation. ${ }^{\text {a }} \mathrm{CH}$ and OI combined into a single factor. ${ }^{\mathrm{b}} \mathrm{CH}$ and ICSR combined into a single factor. ${ }^{\mathrm{c}}$ ICSR and OI combined into a single factor. ${ }^{\mathrm{d}} \mathrm{CWB}-\mathrm{O}$ and CWB-P combined into a single factor. ${ }^{e} \mathrm{CH}$, OI, ICSR combined into a single factor. ${ }^{\mathrm{f}} \mathrm{CH}$, OI, ICSR combined into a single factor, CWB-O and CWB-P combined into a single factor. ${ }^{\circ}$ Harman's single-factor model; all variables combined into a single factor.

We then carried out a CFA on the full measurement model. The measurement model fit well, and all indices were within the range of acceptable models $\left(\chi^{2}(\mathrm{df})=634.858 ; \mathrm{df}=424 ; \chi^{2} / \mathrm{df}=1.519 ; \mathrm{IFI}=\right.$ $0.934 ; \mathrm{TLI}=0.937 ; \mathrm{CFI}=0.943$; RMSEA $=0.045$ ). To analyze whether all variables in our study were distinct, we carried out a series of nested model comparisons, as described in Table 2. Results revealed that all indices of our full measurement model, including five distinct variables, were significantly better than other models. This suggests that all variables were distinct in this study and, therefore, appropriate for inclusion in next analysis.

\subsection{Test of Hypotheses}

We used hierarchical multiple regressions to test $\mathrm{H} 1$ and $\mathrm{H} 2$, and hierarchical moderated regression to test H3 [80]. We tested the moderated mediation using the steps outlined by Preacher, Rucker, and Hayes [81]. In addition, we used the bootstrap technique to confirm the mediation process and tested the moderated mediation model hypothesis [82]. 


\subsubsection{Test of $\mathrm{H} 1$ and $\mathrm{H} 2$}

$\mathrm{H} 1 \mathrm{a}$ and $\mathrm{H} 1 \mathrm{~b}$ illustrate that corporate hypocrisy is negatively related to CWB-O (H1a) and CWB-I ( $\mathrm{H} 1 \mathrm{~b})$. $\mathrm{H} 2 \mathrm{a}$ and $\mathrm{H} 2 \mathrm{~b}$ assume that organizational identification mediates the relationship between corporate hypocrisy and CWB-O (H2a), or CWB-I (H2b). We tested for mediation following the steps outlined by Baron and Kenny [83]. All the results are shown in Table 3.

Table 3. Results of the hierarchical regression analysis of mediation.

\begin{tabular}{|c|c|c|c|c|c|c|c|}
\hline \multirow{2}{*}{$\begin{array}{c}\text { Dependent Variable } \\
\text { Model } \\
\end{array}$} & \multirow{2}{*}{$\begin{array}{l}\text { OI } \\
\text { M1 }\end{array}$} & \multicolumn{3}{|c|}{ CWB-O } & \multicolumn{3}{|c|}{ CWB-P } \\
\hline & & M2 & M3 & M4 & M5 & M6 & M7 \\
\hline \multicolumn{8}{|l|}{ Step 1: control variables } \\
\hline Age & 0.010 & -0.001 & 0.000 & 0.001 & 0.005 & 0.007 & 0.007 \\
\hline Sex & -0.052 & $-0.191 *$ & $-0.313 * *$ & $-0.168 *$ & $-0.206^{*}$ & $-0.368 * *$ & $-0.212 *$ \\
\hline Education & 0.023 & 0.010 & 0.095 & -0.007 & 0.031 & 0.060 & 0.034 \\
\hline \multicolumn{8}{|l|}{$\begin{array}{l}\text { Step 2: independent } \\
\text { variable }\end{array}$} \\
\hline $\mathrm{CH}$ & $-0.331 * *$ & $0.602 * *$ & & $0.556^{* *}$ & $0.636^{* *}$ & & $0.599 * *$ \\
\hline \multicolumn{8}{|l|}{ Step 3: mediator variable } \\
\hline OI & & & $-0.445^{* *}$ & $-0.137^{* *}$ & & $-0.444^{*}$ & -0.113 \\
\hline \multicolumn{8}{|l|}{ Overall model } \\
\hline$R^{2}$ & $0.193^{* *}$ & $0.544^{* *}$ & $0.209 * *$ & $0.557 * *$ & $0.498^{* *}$ & $0.178^{* *}$ & $0.505 *$ \\
\hline$\Delta R^{2}$ & $0.181^{* *}$ & $0.537^{* *}$ & $0.197 * *$ & $0.548^{* *}$ & $0.490 * *$ & $0.165^{* *}$ & 0.495 * \\
\hline $\mathrm{F}$ & $15.222 * *$ & $75.806^{* *}$ & 16.820 ** & $63.556 * *$ & $62.931 * *$ & $13.721 * *$ & $51.564^{* *}$ \\
\hline
\end{tabular}

Notes: $\mathrm{n}=259,{ }^{* *} p<0.01, * p<0.05$.

The results in model 2 and model 5 of Table 3 show that corporate hypocrisy is significantly negatively related to both CWB-O $(\beta=0.602, p<0.01)$ and CWB-I $(\beta=0.556, p<0.01)$, which means H1a and H1b were supported.

In addition, model 1 shows that corporate hypocrisy negatively effects organizational identification $(\beta=-0.331, p<0.01)$, and model 3 and model 6 show that organizational identification negatively relates to both CWB-O $(\beta=-0.445, p<0.01)$ and CWB-I $(\beta=-0.444, p<0.05)$. Thus, the next two requirements of mediation were met.

With regard to $\mathrm{CWB}-\mathrm{O}$, when both $\mathrm{CH}$ and $\mathrm{OI}$ were put into the regression equation (model $4)$, both corporate hypocrisy $(\beta=0.556, p<0.01)$ and organizational identification $(\beta=-0.137, p<$ 0.01) remained significant, indicating partial mediation, so that organizational identification partially mediates the relationship between corporate hypocrisy and CWB-O; thus, H2a was supported. With regard to CWB-I, when both corporate hypocrisy and organizational identification were entered into the model simultaneously (model 7), however, corporate hypocrisy remained significant but the mediator item was not significant ( $\beta=-0.113, p>0.05$ ); thus, $\mathrm{H} 2 \mathrm{~b}$ was not supported.

\subsubsection{Test of $\mathrm{H} 3$}

Our next hypothesis predicted that the relationship between corporate hypocrisy and organizational identification is moderated by the perceived importance of CSR (H3). Based on the test of model 8 and model 9 of Table 4 , the interaction item from model 10 was significant $(\beta=$ $-0.137, p<0.01)$, which reveals that the moderator interacts with corporate hypocrisy significantly to predict organizational identification. Therefore, H3 was supported. 
Table 4. Results of the hierarchical regression analysis of moderation.

\begin{tabular}{|c|c|c|c|}
\hline \multirow{2}{*}{$\begin{array}{c}\text { Dependent Variable } \\
\text { Model }\end{array}$} & \multicolumn{3}{|c|}{ OI } \\
\hline & M8 & M9 & M10 \\
\hline \multicolumn{4}{|l|}{ Step 1: control variables } \\
\hline Age & 0.078 & 0.081 & 0.078 \\
\hline Sex & -0.032 & -0.035 & -0.023 \\
\hline Education & 0.020 & 0.012 & -0.015 \\
\hline \multicolumn{4}{|c|}{ Step 2: independent variable } \\
\hline $\mathrm{CH}$ & $-0.433^{* *}$ & $-0.411^{* *}$ & $0.356^{* *}$ \\
\hline \multicolumn{4}{|l|}{ Step 3: moderator variable } \\
\hline ICSR & & 0.084 & 0.052 \\
\hline \multicolumn{4}{|l|}{ Step 4: interaction term } \\
\hline $\mathrm{CH}^{*} \mathrm{ICSR}$ & & & $-0.317^{* *}$ \\
\hline \multicolumn{4}{|l|}{ Overall model } \\
\hline $\mathrm{R}^{2}$ & $0.193 * *$ & $0.200 * *$ & $0.315^{* *}$ \\
\hline$\Delta \mathrm{R}^{2}$ & $0.181 * *$ & $0.184^{* *}$ & $0.299 * *$ \\
\hline $\mathrm{F}$ & $15.222^{* *}$ & $12.632 * *$ & $19.301 * *$ \\
\hline
\end{tabular}

Plots for the interactions are shown in Figure 2. The organizational identification drops more dramatically when the level of perceived importance of CSR is high.

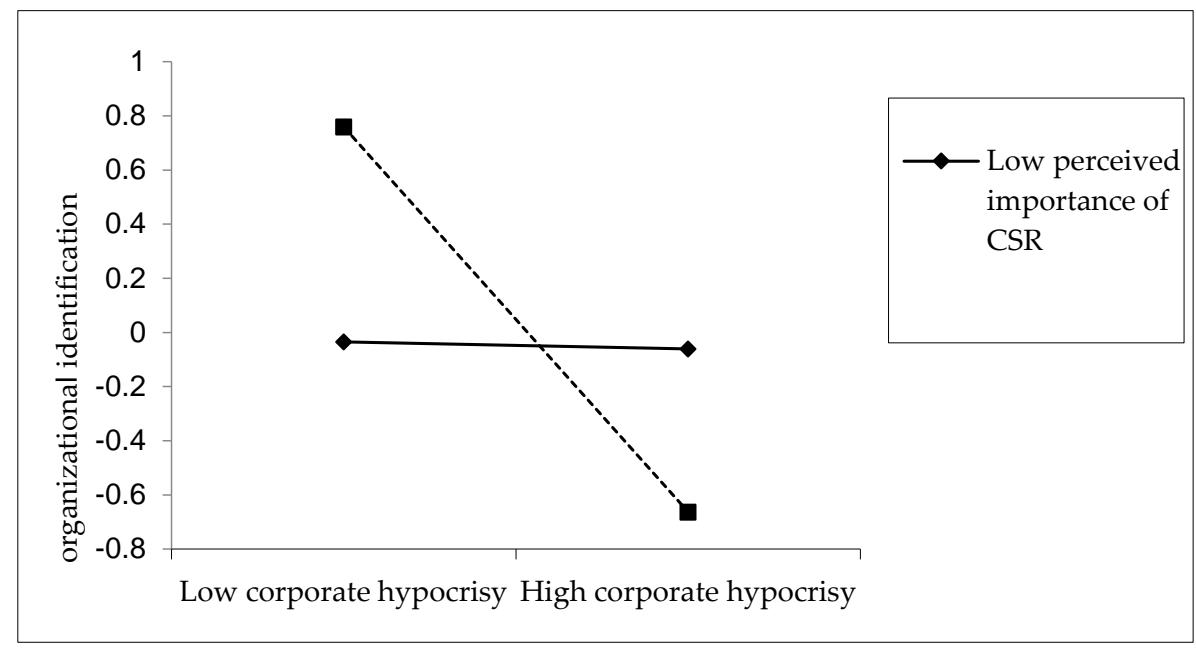

Figure 2. Plots of the moderated relationships.

\subsubsection{Test of $\mathrm{H} 4$}

To assess moderated mediation [80], we should first demonstrate the mediation of organizational identification. Since $\mathrm{H} 2 \mathrm{~b}$ was not supported in Table 3, the mediating effect of organizational identification is not significant between corporate hypocrisy and CWB-I, leading to the failure of $\mathrm{H} 4 \mathrm{~b}$. The results in Table 3 support $\mathrm{H} 2 \mathrm{a}$, so that organizational identification partially mediates the relationship between corporate hypocrisy and CWB-O. With regard to the mediation process of organizational identification between corporate hypocrisy and CWB-O, apart from Baron and Kenny's steps, we also tried the Sobel test and bootstrapping technique [81,82] to confirm H2a, which helps to observe the mediation process more clearly as the corporate hypocrisy coefficient only slightly decreases from models 2 to model 4 in Table 3. 
We estimated direct and indirect effects with the symmetric and 95\% bias-corrected bootstrapped confidence intervals for path estimates [82], with the results shown in Table 5. From Table 5, the mediation of organizational identification was confirmed at $95 \% \mathrm{CI}[0.008,0.093]$ (indirect effect $=0.043$, $p<0.05)$, thus proving H2a once again. However, the mediating effect is not full, as the direct effect is more significant, as shown in Table 5 (direct effect $=0.57, p<0.01$ ), indicating the partial mediation process. The mediating effect path is shown in Figure 3.

Table 5. Bootstrapping results of the mediation model.

\begin{tabular}{ccccccc}
\hline Path & Effect & SE & $\mathbf{t} / \mathbf{z}$ & $p$ & LLCI $^{\mathbf{a}}$ & ULCI $^{\mathbf{a}}$ \\
\hline \multirow{2}{*}{ CH $\rightarrow$ CWB-O } & Direct effect & SE & $\mathbf{t}$ & $p$ & LLCI $^{\mathbf{a}}$ & ULCI $^{\mathbf{a}}$ \\
\cline { 2 - 7 } & 0.57 & 0.039 & 14.601 & 0.000 & 0.493 & 0.646 \\
\hline \multirow{2}{*}{ CH $\rightarrow$ OI } & Co effect & SE & $\mathbf{t}$ & $p$ & LLCI $^{\mathbf{a}}$ & ULCI $^{\mathbf{a}}$ \\
\cline { 2 - 7 } & -0.330 & 0.043 & -7.663 & 0.000 & -0.414 & -0.245 \\
\hline \multirow{2}{*}{ OI $\rightarrow$ CWB-O } & Co effect & SE & $\mathbf{t}$ & $p$ & LLCI $^{\mathbf{a}}$ & ULCI $^{\mathbf{a}}$ \\
\cline { 2 - 7 } & -0.132 & 0.051 & -2.583 & 0.010 & -0.232 & -0.031 \\
\hline \multirow{2}{*}{$\mathrm{CH} \rightarrow$ OI $\rightarrow$ CWB-O } & Indirect effect & SE & $\mathbf{z}$ & $p$ & LLCI $^{\mathbf{a}}$ & ULCI $^{\mathbf{a}}$ \\
\cline { 2 - 7 } & 0.043 & 0.018 & 2.429 & 0.015 & 0.008 & 0.093 \\
\hline
\end{tabular}

Note: $\mathrm{LL}=$ lower limit, $\mathrm{UL}=$ upper limit, $\mathrm{CI}=$ confidence interval. ${ }^{\text {a }}$ Bootstrapped at sample size $=1000$. The arrow means the path from one variable to another variable in the supposed model.

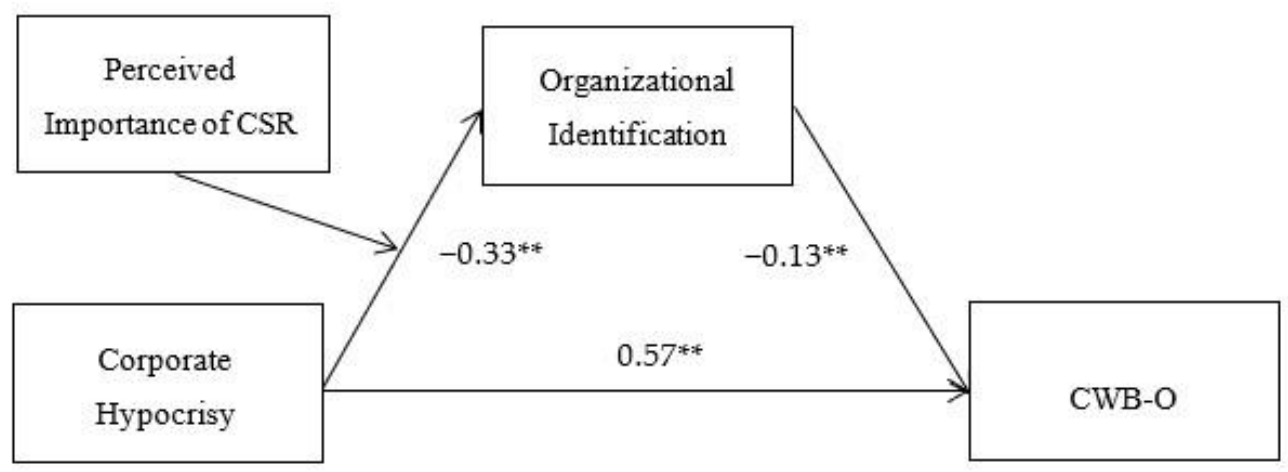

Figure 3. Mediation effect path.

Furthermore, we tested the moderated mediation model of corporate hypocrisy to CWB-O with the mediating effect of OI and moderating effect of perceived importance of CSR using the bootstrapping way. In Table 6, we can find that the confidence interval for the difference between the mediating effects does not cross the value of zero when the perceived importance of CSR is high, but cross the number zero when the level of moderator is low. This means that the mediating effect of OI between corporate hypocrisy and CWB-O is stronger and more significant for higher levels of perceived importance of CSR. Therefore, the mediation of organizational identification is moderated by the perceived importance of CSR, supporting H4a.

Table 6. Bootstrapping results of the moderated mediation model to CWB-O.

\begin{tabular}{ccccccc}
\hline Mediator & Moderator & $\begin{array}{c}\text { Level of } \\
\text { ICSR }\end{array}$ & $\begin{array}{c}\text { Conditional } \\
\text { Indirect Effect }\end{array}$ & SE & LLCI $^{\text {a }}$ & ULCI $^{\text {a }}$ \\
\hline OI & ICSR & Low (2.74) & 0.0037 & 0.0078 & -0.0070 & 0.0283 \\
OI & ICSR & High (4.18) & 0.0674 & 0.0321 & 0.0086 & 0.1314 \\
\hline
\end{tabular}

Note: $\mathrm{LL}=$ lower limit, $\mathrm{UL}=$ upper limit $\mathrm{CI}=$ confidence interval. ${ }^{\text {a }}$ Bootstrapped at sample size $=1000$. 


\section{Discussion}

In response to calls for future studies on the perceptions and consequences of corporate hypocrisy across various industries and from an intercultural perspective [7], we explored the processes of mediation and moderation linking corporate hypocrisy to CWB. A positive relationship was found between corporate hypocrisy and CWB. We also proved that organizational identification partially mediated the relationship between corporate hypocrisy and CWB-O and, further, the strength of the relationship between corporate hypocrisy and OI was moderated by employees' perceived importance of CSR. By analyzing data from 259 employees in a manufacturing organization in China, the moderated mediation model was found only when the outcome variable was CWB-O.

\subsection{Contributions and Implications}

Consistent with social identity theory, we found that the corporate hypocrisy situation impacts significantly on both CWB against the organization and CWB against the individual. In addition, organizational identification works as the mediation, which suggests that employees would react to the unethical and insincere hypocrisy perception by reducing organizational identification, thus leading to deviant behaviors. Furthermore, employees' perceived importance of CSR moderates the relationship between corporate hypocrisy and organizational identification and the mediation effect to CWB-O, such that these relationships are more pronounced for employees with higher levels of perceived importance of CSR. By shedding light on the nature of corporate hypocrisy, this research suggests that when employees perceive corporate hypocrisy, organizational identification is damaged and CWB-O is enhanced, especially if employees place more importance on CSR. The results have several implications both theoretically and practically.

\subsubsection{Theoretical Contributions}

In theoretical terms, by linking employees' perceptions of corporate hypocrisy with their CWB, our research uncovered the negative influence of corporate hypocrisy on employees, an issue needing more attention thus far. In doing so, we integrated a macrolevel concept of corporate hypocrisy with microlevel variables related to employees. Researchers interested in corporate hypocrisy have mostly focused on customers' attitudes before (e.g., [7,13,16,84]). This study contributes to the corporate hypocrisy literature by extending the research scope to include its consequences on the inner stakeholders. Apart from the damaged fame, companies' hypocritical behavior will also cause a negative reaction of employees, like CWB.

Besides, our research contributes to social identity theory by proving the mediating effect between corporate hypocrisy and CWB-O, which adds more evidence to the explanation mechanism of organizational identification implied in the field of organizational ethics, CSR, and employees' behaviors, in addition to the previous research (e.g., [57-60]). Once again, the negative relationship between organizational identity and CWB was verified [30], enriching the application of OI theory in the field of CWB.

Moreover, our research suggests that the organizational variable influences employees' attitudes and behaviors depending on employees' different values. When employees have a higher value of CSR, they are more sensitive to the CSR slogan or the company's external publicity, which makes it more likely that the hypocrisy of the company is discovered. Concerning their emphasis on CSR, they will have a more radical reaction to such inconsistencies of the company's saying and doing, like reducing their identification with the company or conducting CWB. Like El-Kassar et al. [66], who found that employees' perceived importance of CSR moderated the relationship between CSR and organizational identification, our findings indicate that the moderator of ICSR in the CSR-related context deserves attention, which has enriched research on employees' values.

Finally, considering the differentiation between CWB targets allows us to logically reason that their triggers might also be distinguished [85]. Through our results, employees who identify less with 
the organization will only trigger organization-targeted outcomes through the mediation mechanism. The results are in line with previous findings that CWB-O is highly related to organization-targeted constraints, such as the organizational culture and practices, while CWB-I is highly correlated to interpersonal factors [86]. In this way, the attitudes or feelings towards the company may be more closely related to CWB against the organization as a whole, instead of towards coworkers. Thus, we have made some explorations on the meaningful subdivision of CWB.

\subsubsection{Practical Implications}

In practical terms, different from past research, which has always paid attention to the benefits of CSR and encouraged companies to participate in CSR activities (e.g., [87-89]), this paper tells us that if the CSR commitment cannot be fulfilled reasonably, it will bring about consequences that harm the interests of the company. For example, our results warn organizations that corporate hypocrisy will lead to unethical CWB within the organization, which may damage the corporation. Companies should be very careful when making and implementing CSR publicity. It is not enough for companies to behave in a socially responsible manner in public, while their real actions should strictly follow their slogans as well. The "think in one way and behave in another" plot must be forbidden as its CSR campaigns must be credible if the company expects to achieve the desired results [12].

Besides, whether the organization fulfill its promise in a sincere and trustworthy way may influence the organizational identification of its members. If the company fails to achieve its promise of CSR, choosing a hypocritical way to make profits from publicity will result in employees reducing their sense of identity and loyalty universally through CWB like depression, lower performance, or breach of confidence, which are detrimental to their company. Only extrinsic motives of CSR perceived by employees can enhance their organizational commitment [46].

In addition, organizations need to be alert to changes in employees' sense of identity, since our study showed that employees' disapproval will be more reflected in the CWB-O. This result extended the negative influence from OI to CWB in a more nuanced way (e.g., [30,90]). To maintain the belongingness and loyalty of employees, the company must avoid unethical and dishonest behaviors like corporate hypocrisy. The organization should establish a code of ethics and rules for its members and steadfastly assume its social responsibilities to create a sincerely moral climate instead.

Lastly, companies should realize that internal stakeholders, such as employees, can be important overseers of corporate hypocrisy. Our results show that employees with high perceived importance of CSR could react more sensitively to corporate hypocrisy, by reducing their organizational identification more significantly. Since corporate CSR awareness has increased obviously in recent decades all over the world [91], more employees will become aware of the significance of CSR-related issues. It is recommended that when determining CSR activities, corporations could take into consideration what employees perceive as important and align the corporate interests with employees' values to avoid hypocrisy.

\subsection{Limitations and Future Research}

There remain some limitations in this study that must be noted and potentially addressed in the future. Firstly, we used self-report scales to obtain the data we required. Given the controversial and disguised traits of corporate hypocrisy, we may argue that self-report measures might actually be the most valid measurement method for most of the chosen variables, as employees are best placed to report their perceived corporate hypocrisy situation and their own levels of CWB. Although statistical analysis has indicated that common method bias was not a major concern in this study, we suggest future research uses different sources of response to avoid the potential issues associated with common method bias. The choice of sample in our study also represents a further data limitation that needs to be taken into consideration. All of our data came from one organization, which may reduce the variation of corporate hypocrisy at the organizational level. Responses could be collected from larger-scale and heterogeneous samples instead in future exploration. 
Secondly, given that the concept of corporate hypocrisy is relatively new, the definition or scale of this variable is comparatively simple. Existing studies have also used the same scale concerning the issue of corporate hypocrisy (e.g., $[7,13,16,84])$. Besides, there are rare references available on corporate hypocrisy in general. Future research can make more of a commitment to concept expansion and measurement enrichment of corporate hypocrisy. We also expect more relevant studies focusing on corporate hypocrisy, such as exploring its antecedents and effects, both from internal and external perspectives. For example, the dispersal of ethical responsibilities has been proven to be one of the sources of unethical decisions [92]. The scandals of corporate hypocrisy may reveal the extent of ethical responsibilities' dispersal [93], as agents could make decisions on behalf of the principal, seeking risk to maximize profit through corporate hypocrisy.

There may be further reasons for the failure of $\mathrm{H} 2 \mathrm{~b}$ and $\mathrm{H} 4 \mathrm{~b}$. Our study proved only partial mediation of organizational identification between corporate hypocrisy and CWB-O, while the mediation hypothesis between corporate hypocrisy and CWB-I was not supported. The results indicate that the suitability of our CWB classification is also worth being discussed. Besides, considering the insufficiency of the mediating effect, the mediator variable selected in our study may not be the best. Future research should explore the roles of various mediating variables, such as negative emotions, employee commitment, or job stress, in order to gain a clearer understanding of the influence mechanism. Future research can also consider some alternate or additional theoretical perspectives, such as cognitive dissonance theory or attribution theory, to account for the negative reactions of employees. In other aspects, not all employees may express protest and disapproval, and employees may tend to learn from unethical $\mathrm{CH}$ behaviors, by involving in collective reflection with the organization and managerial coaching [94]. Thus, team reflexivity may be regarded as a critical channel for employees to learn from corporate hypocritical behavior, like its role as a group effect [95].

Since corporate social responsibility has been viewed and realized from different angles and in multiple ways all over the world, the challenges in CSR implementation may appear differently from region to region, depending on its economy level or government devotion in the promotion work [96]. We should take the economic, political, and cultural elements into consideration when thinking about CSR or corporate hypocrisy. As the theorization of the CSR framework has regarded companies' demands for legitimacy with their core stakeholders or the environment they operate in [97], more theoretical research on corporate hypocrisy may also deal with stakeholders' or society's involvements.

\section{Conclusions}

Previous studies have explored the impact of corporate hypocrisy mainly on consumers' attitudes, ignoring the perspective of other stakeholders. This study focused on the consequence of corporate hypocrisy on employees to help fill the gap. In conclusion, corporate hypocrisy in CSR is positively related to both CWB against the organization and CWB against coworkers, proving its negative effects on employees. Organizational identification partially mediates the relationship between corporate hypocrisy and CWB-O, which is moderated by employees' perceived importance of CSR, formulating a moderated mediation model. In other words, employees with high levels of perceived importance of CSR are less likely to identify with organizations involved in corporate hypocrisy and thus more likely to engage in CWB-O. However, two of our hypotheses were not supported, indicating the weak relationship between organizational identification and CWB-I. Our findings provide contributions enriching the literature of corporate hypocrisy, OI, and CWB. We also suggest that companies should be more careful in avoiding corporate hypocrisy, given its potential negative consequences in terms of both the attitudinal and behavioral outcomes of employees. Besides, companies should set CSR goals that are aligned with employees' values, which helps to maintain the identification of employees with organizations. Corporate hypocrisy will ultimately harm the organization itself, thus companies should carry out their CSR promise in an ethical, honest, and sincere way to benefit the organization, the staff, and the whole society. This paper may also contain some shortcomings in data collection 
and measurement as well as the mediator chosen. We hope more explorations focused on corporate hypocrisy occur in the near future.

Author Contributions: Conceptualization, Q.M. and J.Z.; formal analysis, J.Z.; methodology, Q.M. and J.Z.; writing —original draft, J.Z. and Q.M.; writing—review and editing, Q.M. and J.Z. All authors have read and agreed to the published version of the manuscript.

Conflicts of Interest: The authors declare no conflict of interest.

\section{References}

1. Schrempf-Stirling, J.; Palazzo, G.; Phillips, R.A. Historic corporate social responsibility. Acad Manag. Rev. 2016, 41, 700-719. [CrossRef]

2. Du, S.; Bhattacharya, C.B.; Sen, S. Reaping relational rewards from corporate social responsibility: The role of competitive positioning. Int. J. Res. Mark. 2007, 24, 224-241. [CrossRef]

3. Arevalo, J.A.; Aravind, D. Strategic outcomes in voluntary CSR: Reporting economic and reputational benefits in principles-based initiatives. J. Bus. Ethics 2017, 144, 201-217. [CrossRef]

4. Malik, M. Value-Enhancing Capabilities of CSR: A Brief Review of Contemporary Literature. J. Bus. Ethics 2015, 127, 419-438. [CrossRef]

5. Jones, B.; Bowd, R.; Tench, R. Corporate irresponsibility and corporate social responsibility: Competing realities. Soc. Responsib. J. 2009, 5, 300-310. [CrossRef]

6. Yoon, S.; Lam, T. The illusion of righteousness: Corporate social responsibility practices of the alcohol industry. BMC Public Health 2013, 13, 630-640. [CrossRef]

7. Wagner, T.; Lutz, R.J.; Weitz, B.A. Corporate Hypocrisy: Overcoming the Threat of Inconsistent Corporate Social Responsibility Perceptions. J. Mark. 2009, 73, 77-91. [CrossRef]

8. Rhodes, C. Democratic business ethics: Volkswagen's emissions scandal and the disruption of corporate sovereignty. Organ. Stud. 2016, 37, 1501-1518. [CrossRef]

9. Siano, A.; Vollero, A.; Conte, F.; Amabile, S. "More than words": Expanding the taxonomy of greenwashing after the Volkswagen scandal. J. Bus. Res. 2017, 71, 27-37. [CrossRef]

10. The Investigation Report of the $¥ 0.1$ Donation Event by Nongfushanquan. Available online: http://www. gongyishibao.com/zhuan/nongfushanquan/ (accessed on 1 December 2018).

11. Edmondson, D.R.; Ward, C.B.; Roy, D.P. Is McDonald's Clowning Around with Ronald McDonald House Charities? J. Crit. Incid. 2017, 10, 35-37.

12. Lahoti, S.; Johnson, C.M.; Holloway, B.B. Corporate social responsibility authenticity: Investigating its antecedents and outcomes. J. Bus. Res. 2016, 69, 1242-1249.

13. Shim, K.; Yang, S. The effect of bad reputation: The occurrence of crisis, corporate social responsibility, and perceptions of hypocrisy and attitudes toward a company. Public Relat. Rev. 2016, 42, 68-78. [CrossRef]

14. Yoon, Y.; Gürhan Canli, Z.; Schwarz, N. The effect of corporate social responsibility (CSR) activities on companies with bad reputations. J. Consum. Psychol. 2006, 16, 377-390. [CrossRef]

15. Fassin, Y.; Buelens, M. The hypocrisy-sincerity continuum in corporate communication and decision making: A model of corporate social responsibility and business ethics practices. Manag. Decis. 2011, 49, 586-600. [CrossRef]

16. Arli, D.; Grace, A.; Palmer, J.; Pham, C. Investigating the direct and indirect effects of corporate hypocrisy and perceived corporate reputation on consumers' attitudes toward the company. J. Retail. Consum. Serv. 2017, 37, 139-145. [CrossRef]

17. Ford, R.C.; Richardson, W.D. Ethical decision making: A review of the empirical literature. J. Bus. Ethics 1994, 13, 205-221. [CrossRef]

18. Hansen, S.D.; Dunford, B.B.; Boss, A.D.; Boss, R.W.; Angermeier, I. Corporate Social Responsibility and the Benefits of Employee Trust: A Cross-Disciplinary Perspective. J. Bus. Ethics 2011, 102, 29-45. [CrossRef]

19. Newman, A.; Nielsen, I.; Miao, Q. The impact of employee perceptions of organizational corporate social responsibility practices on job performance and organizational citizenship behavior: Evidence from the Chinese private sector. Int. J. Hum. Resour. Manag. 2015, 26, 1226-1242. [CrossRef]

20. Shin, I.; Hur, W.; Kim, M.; Kang, S. Hidden Roles of CSR: Perceived Corporate Social Responsibility as a Preventive against Counterproductive Work Behaviors. Sustainability 2017, 9, 955. [CrossRef] 
21. Hur, W.M.; Moon, T.W.; Lee, H.G. Employee engagement in CSR initiatives and customer-Directed counterproductive work behavior (CWB): The mediating roles of organizational civility norms and job calling. Corp. Soc. Resp. Environ. Ma 2018, 25, 1087-1098. [CrossRef]

22. Bolino, M.C.; Klotz, A.C. The paradox of the unethical organizational citizen: The link between organizational citizenship behavior and unethical behavior at work. Curr. Opin. Psychol. 2015, 6, 45-49. [CrossRef]

23. Cole, M.S.; Bruch, H. Organizational identity strength, identification, and commitment and their relationships to turnover intention: Does organizational hierarchy matter? J. Organ. Behav. 2006, 27, 585-605. [CrossRef]

24. Dukerich, J.M.; Golden, B.R.; Shortell, S.M. Beauty is in the eye of the beholder: The impact of organizational identification, identity, and image on the cooperative behaviors of physicians. Admin Sci. Quart. 2002, 47, 507-533. [CrossRef]

25. Rodrigo, P.; Arenas, D. Do employees care about CSR programs? A typology of employees according to their attitudes. J. Bus. Ethics 2008, 83, 265-283. [CrossRef]

26. Jones, D.A. Does serving the community also serve the company? Using organizational identification and social exchange theories to understand employee responses to a volunteerism programme. J. Occup. Organ. Psychol. 2010, 83, 857-878. [CrossRef]

27. De Roeck, K.; Delobbe, N. Do environmental CSR initiatives serve organizations' legitimacy in the oil industry? Exploring employees' reactions through organizational identification theory. J. Bus. Ethics 2012, 110, 397-412. [CrossRef]

28. Glavas, A.; Godwin, L.N. Is the Perception of 'Goodness' Good Enough? Exploring the Relationship between Perceived Corporate Social Responsibility and Employee Organizational Identification. J. Bus. Ethics 2013, 114, 15-27. [CrossRef]

29. Carmeli, A.; Gilat, G.; Waldman, D.A. The role of perceived organizational performance in organizational identification, adjustment and job performance. J. Manag. Stud. 2007, 44, 972-992. [CrossRef]

30. Ciampa, V.; Sirowatka, M.; Schuh, S.C.; Fraccaroli, F.; van Dick, R. Ambivalent Identification as a Moderator of the Link Between Organizational Identification and Counterproductive Work Behaviors. J. Bus. Ethics 2019, 8, 1-16. [CrossRef]

31. Trevino, L.K. Ethical decision making in organizations: A person-situation interactionist model. Acad Manag. Rev. 1986, 11, 601-617. [CrossRef]

32. Batson, C.D.; Collins, E.; Powell, A.A. Doing business after the fall: The virtue of moral hypocrisy. J. Bus. Ethics 2006, 66, 321-335. [CrossRef]

33. Aaker, J.L. Dimensions of brand personality. J. Mark. Res. 1997, 34, 347-356. [CrossRef]

34. Ha-Brookshire, J. Toward moral responsibility theories of corporate sustainability and sustainable supply chain. J. Bus. Ethics 2017, 145, 227-237. [CrossRef]

35. Jahdi, K.S.; Acikdilli, G. Marketing communications and corporate social responsibility (CSR): Marriage of convenience or shotgun wedding? J. Bus. Ethics 2009, 88, 103-113. [CrossRef]

36. Brunsson, N. The Organization of Hypocrisy: Talk, Decisions and Actions in Organizations; John Wiley \& Sons: Chichester, UK, 1989.

37. La Cour, A.; Kromann, J. Euphemisms and hypocrisy in corporate philanthropy. Bus. Ethics 2011, 20, $267-279$. [CrossRef]

38. Bae, J.; Cameron, G.T. Conditioning effect of prior reputation on perception of corporate giving. Public Relat. Rev. 2006, 32, 144-150. [CrossRef]

39. Spector, P.E.; Fox, S. An emotion-centered model of voluntary work behavior: Some parallels between counterproductive work behavior and organizational citizenship behavior. Hum. Resour Manag. Rev. 2002, 12, 269-292. [CrossRef]

40. Martinko, M.J.; Gundlach, M.J.; Douglas, S.C. Toward an integrative theory of counterproductive workplace behavior: A causal reasoning perspective. Int. J. Select. Assess 2002, 10, 36-50. [CrossRef]

41. Schein, E.H. The Corporate Culture Survival Guide; John Wiley \& Sons: San Francisco, CA, USA, 2009; Volume 158.

42. Bennett, R.J.; Robinson, S.L. Development of a measure of workplace deviance. J. Appl. Psychol. 2000, 85, 349-360. [CrossRef]

43. Maloney, P.W.; Grawitch, M.J.; Barber, L.K. The multi-factor structure of the Brief Self-Control Scale: Discriminant validity of restraint and impulsivity. J. Res. Pers. 2012, 46, 111-115. [CrossRef] 
44. Grijalva, E.; Newman, D.A. Narcissism and counterproductive work behavior (CWB): Meta-analysis and consideration of collectivist culture, Big Five personality, and narcissism's facet structure. Appl. Psychol. 2015, 64, 93-126. [CrossRef]

45. Fida, R.; Paciello, M.; Tramontano, C.; Barbaranelli, C.; Farnese, M.L. “Yes, I Can": The protective role of personal self-efficacy in hindering counterproductive work behavior under stressful conditions. Anxiety Stress Coping 2015, 28, 479-499. [CrossRef] [PubMed]

46. Lee, S.; Seo, Y.W. Corporate social responsibility motive attribution by service employees in the parcel logistics industry as a moderator between CSR perception and organizational effectiveness. Sustainability 2017, 9, 355. [CrossRef]

47. Ashforth, B.E.; Mael, F. Social Identity Theory and the Organization. Acad Manag. Rev. 1989, 14, $20-39$. [CrossRef]

48. Ellemers, N.; Pagliaro, S.; Barreto, M. Morality and behavioural regulation in groups: A social identity approach. Eur. Rev. Soc. Psychol. 2013, 24, 160-193. [CrossRef]

49. Smith, W.J.; Wokutch, R.E.; Harrington, K.V.; Dennis, B.S. An examination of the influence of diversity and stakeholder role on corporate social orientation. Bus. Soc. 2001, 40, 266-294. [CrossRef]

50. Mael, F.; Ashforth, B.E. Alumni and their alma mater: A partial test of the reformulated model of organizational identification. J. Organ. Behav. 1992, 13, 103-123. [CrossRef]

51. Schrodt, P. The relationship between organizational identification and organizational culture: Employee perceptions of culture and identification in a retail sales organization. Commun. Stud. 2002, 53, 189-202. [CrossRef]

52. Supanti, D.; Butcher, K.; Fredline, L. Enhancing the employer-employee relationship through corporate social responsibility (CSR) engagement. Int. J. Contemp. Hosp. Manag. 2015, 27, 1479-1498. [CrossRef]

53. Dutton, J.E.; Dukerich, J.M.; Harquail, C.V. Organizational images and member identification. Admin. Sci. Quart. 1994, 39, 239-263. [CrossRef]

54. Hess, D.; Rogovsky, N.; Dunfee, T.W. The Next Wave of Corporate Community Involvement: Corporate Social Initiatives. Calif. Manag. Rev. 2002, 44, 110-125. [CrossRef]

55. Peterson, D.K. The Relationship between Perceptions of Corporate Citizenship and Organizational Commitment. Bus. Soc. 2004, 43, 296-319. [CrossRef]

56. Brammer, S.; Millington, A.; Rayton, B. The contribution of corporate social responsibility to organizational commitment. Int. J. Hum. Resour. Manag. 2007, 18, 1701-1719. [CrossRef]

57. Turker, D. How Corporate Social Responsibility Influences Organizational Commitment. J. Bus. Ethics 2009, 89, 189-204. [CrossRef]

58. Rego, A.; Leal, S.; Cunha, M.P.; Faria, J.; Pinho, C. How the perceptions of five dimensions of corporate citizenship and their inter-inconsistencies predict affective commitment. J. Bus. Ethics 2010, 94, 107-127. [CrossRef]

59. Stites, J.P.; Michael, J.H. Organizational commitment in manufacturing employees: Relationships with corporate social performance. Bus. Soc. 2011, 50, 50-70. [CrossRef]

60. Farooq, O.; Payaud, M.; Merunka, D.; Valette-Florence, P. The Impact of Corporate Social Responsibility on Organizational Commitment: Exploring Multiple Mediation Mechanisms. J. Bus. Ethics 2014, 125, 563-580. [CrossRef]

61. Goswami, S.; Ha-Brookshire, J.E. Exploring U.S. Retail Employees' Experiences of Corporate Hypocrisy. Organ. Manag. J. 2016, 13, 168-178. [CrossRef]

62. Blader, S.L.; Patil, S.; Packer, D.J. Organizational identification and workplace behavior: More than meets the eye. Res. Organ. Behav. 2017, 37, 19-34. [CrossRef]

63. Norman, S.M.; Avey, J.B.; Nimnicht, J.L.; Graber Pigeon, N. The Interactive Effects of Psychological Capital and Organizational Identity on Employee Organizational Citizenship and Deviance Behaviors. J. Lead. Organ. Stud. 2010, 17, 380-391. [CrossRef]

64. Ngo, H.; Loi, R.; Foley, S.; Zheng, X.; Zhang, L. Perceptions of organizational context and job attitudes: The mediating effect of organizational identification. Asia Pac. J. Manag. 2013, 30, 149-168. [CrossRef]

65. Kim, H.; Lee, M.; Lee, H.; Kim, N. Corporate social responsibility and employee-company identification. J. Bus. Ethics 2010, 95, 557-569. [CrossRef]

66. El-Kassar, A.; Messarra, L.C.; El-Khalil, R. CSR, organizational identification, normative commitment, and the moderating effect of the importance of CSR. J. Dev. Areas 2017, 51, 409-424. [CrossRef] 
67. Aguilera, R.V.; Rupp, D.E.; Williams, C.A.; Ganapathi, J. Putting the S back in corporate social responsibility: A multilevel theory of social change in organizations. Acad Manag. Rev. 2007, 32, 836-863. [CrossRef]

68. Singhapakdi, A.; Vitell, S.J.; Rallapalli, K.C.; Kraft, K.L. The perceived role of ethics and social responsibility: A scale development. J. Bus. Ethics 1996, 15, 1131-1140. [CrossRef]

69. Brislin, R.W. Back-translation for cross-cultural research. J Cross Cult. Psychol. 1970, 1, 185-216. [CrossRef]

70. Podsakoff, P.M.; MacKenzie, S.B.; Podsakoff, N.P. Sources of method bias in social science research and recommendations on how to control it. Annu. Rev. Psychol. 2012, 63, 539-569. [CrossRef]

71. Etheredge, J.M. The perceived role of ethics and social responsibility: An alternative scale structure. J. Bus. Ethics 1999, 18, 51-64. [CrossRef]

72. Hunter, E.M.; Penney, L.M. The waiter spit in my soup! Antecedents of customer-directed counterproductive work behavior. Hum. Perform. 2014, 27, 262-281. [CrossRef]

73. Tabachnick, B.G.; Fidell, L.S. Using Multivariate Statistics; Harper Collins: New York, NY, USA, 1996.

74. Podsakoff, P.M.; MacKenzie, S.B.; Lee, J.; Podsakoff, N.P. Common method biases in behavioral research: A critical review of the literature and recommended remedies. J. Appl. Psychol. 2003, 88, 879-903. [CrossRef]

75. Hair, J.F.; Black, W.C.; Babin, B.J.; Anderson, R.E.; Tatham, R.L. Multivariate analysis of data. Porto Alegre 2005, 6, 89-127.

76. Arbuckle, J.L. Amos 7.0 User's Guide; SPSS: Chicago, IL, USA, 2006.

77. Bentler, P.M. Comparative fit indexes in structural models. Psychol. Bull. 1990, 107, 230-246. [CrossRef] [PubMed]

78. Browne, M.W.; Cudeck, R. Alternative ways of assessing model fit. Soc. Method Res. 1992, 21, $230-258$. [CrossRef]

79. Hu, L.; Bentler, P.M. Fit indices in covariance structure modeling: Sensitivity to underparameterized model misspecification. Psychol. Methods 1998, 3, 424-453. [CrossRef]

80. Aiken, L.S.; West, S.G.; Reno, R.R. Multiple Regression: Testing and Interpreting Interactions; Sage: New York, NY, USA, 1991.

81. Preacher, K.J.; Rucker, D.D.; Hayes, A.F. Addressing moderated mediation hypotheses: Theory, methods, and prescriptions. Multivar Behav. Res. 2007, 42, 185-227. [CrossRef]

82. Hayes, A.F. An index and test of linear moderated mediation. Multivar Behav. Res. 2015, 50, 1-22. [CrossRef]

83. Baron, R.M.; Kenny, D.A. The moderator-mediator variable distinction in social psychological research: Conceptual, strategic, and statistical considerations. J. Pers. Soc. Psychol. 1986, 51, 1173-1182. [CrossRef]

84. Kim, H.; Hur, W.; Yeo, J. Corporate brand trust as a mediator in the relationship between consumer perception of CSR, corporate hypocrisy, and corporate reputation. Sustainability 2015, 7, 3683-3694. [CrossRef]

85. Liao, H.; Joshi, A.; Chuang, A. Sticking out like a sore thumb: Employee dissimilarity and deviance at work. Pers. Psychol. 2004, 57, 969-1000. [CrossRef]

86. Fida, R.; Paciello, M.; Tramontano, C.; Fontaine, R.G.; Barbaranelli, C.; Farnese, M.L. An Integrative Approach to Understanding Counterproductive Work Behavior: The Roles of Stressors, Negative Emotions, and Moral Disengagement. J. Bus. Ethics 2015, 130, 131-144. [CrossRef]

87. Lee, K.; Shin, D. Consumers' responses to CSR activities: The linkage between increased awareness and purchase intention. Public Relat. Rev. 2010, 36, 193-195. [CrossRef]

88. Lee, E.M.; Park, S.; Lee, H.J. Employee perception of CSR activities: Its antecedents and consequences. J. Bus. Res. 2013, 66, 1716-1724. [CrossRef]

89. Story, J.; Neves, P. When corporate social responsibility (CSR) increases performance: Exploring the role of intrinsic and extrinsic CSR attribution. Bus. Ethics 2015, 24, 111-124. [CrossRef]

90. Al-Atwi, A.A.; Bakir, A. Relationships between status judgments, identification, and counterproductive behavior. J. Manag. Psychol. 2014, 29, 472-489. [CrossRef]

91. Kolk, A. The social responsibility of international business: From ethics and the environment to CSR and sustainable development. J. World Bus. 2016, 51, 23-34. [CrossRef]

92. Burlea, A.S.; Idowu, S.O. The independence of managers: An ethical dilemma. Int. J. Soc. Entrep. Innov. 2016, 4, 152-171. [CrossRef]

93. Burlea, A.S.; Remmé, J. The dangers of dispersal of responsibilities. Amfiteatru Econ. 2017, 19, 464-476.

94. Matsuo, M. How does managerial coaching affect individual learning? The mediating roles of team and individual reflexivity. Pers. Rev. 2018, 47, 118-132. [CrossRef] 
95. Shin, Y. Positive group affect and team creativity: Mediation of team reflexivity and promotion focus. Small Gr. Res. 2014, 45, 337-364. [CrossRef]

96. Burlea, A.S.; Vertigans, S.; Idowu, S.O. Corporate social responsibility in times of crisis: A summary. In Corporate Social Responsibility in Times of Crisis; Springer: Cham, Switzerland, 2017; pp. 261-264.

97. Li, J. Legitimacy Acquisition of Social Enterprise in China: A Case Study of Canyou Initiative. J. Chin. Gover. 2017, 2, 194-208.

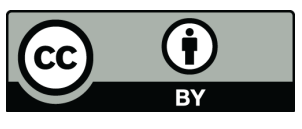

(C) 2020 by the authors. Licensee MDPI, Basel, Switzerland. This article is an open access article distributed under the terms and conditions of the Creative Commons Attribution (CC BY) license (http://creativecommons.org/licenses/by/4.0/). 